\title{
Krzysztof Moraczewski
}

Uniwersytet im. Adama Mickiewicza w Poznaniu kmoracz@amu.edu.pl

\section{MUZYCZNA ZŁOŻONOŚĆ I PEWNA SPECYFICZNA FORMA DOŚWIADCZENIA ESTETYCZNEGO}

Od czasu niemieckiego Sturm und Drang, a zwłaszcza od pism Ludwiga Tiecka i Wilhelma Wackenrodera, opisywanie doświadczania muzyki, szczególnie zaś muzyki instrumentalnej, poprzez odniesienie do wieczności stało się jednym $\mathrm{z}$ naczelnych toposów niemieckiej, a potem europejskiej kultury muzycznej romantyzmu. Wyobrażenie to - wzmocnione wpierw przez Ernsta Theodora Amadeusa Hoffmana, następnie zaś w ramach pewnego sposobu myślenia, który Carl Dahlhaus określił mianem "romantycznej metafizyki muzyki instrumentalnej"1 - zdecydowanym ruchem utorowało sobie drogę $\mathrm{w}$ wiek dwudziesty, pojawiając się zarówno wśród elitarnych estetyków muzycznej awangardy, jak i w popularnej świadomości słuchaczy. Powiązanie muzyka - wieczność, które trafiło nawet do repertuaru hollywoodzkich sloganów (czego przykładem film Wieczna mitość, podobno o Beethovenie), jak większość dzisiejszych banałów jest tylko wykorzenioną postacią historycznie kluczowego doświadczenia.

Myślenie o doświadczaniu muzyki jako „zwierciadła wieczności” nie da się jednak sprowadzić wyłącznie do historycznej kwestii wyobraźni romantycznej i właściwych jej sposobów wypowiadania się. Powracało bowiem na przestrzeni ostatnich dwóch tysiącleci wyjątkowo często i w bardzo zróżnicowanych postaciach: od dyskursów teologicznych po wersje całkowicie

${ }^{1}$ C. Dahlhaus, Idea muzyki absolutnej i inne studia, tłum. A. Buchner, Kraków 1988 
zsekularyzowane. Jako przykłady wymieńmy Augustiańskie, a w swym rodowodzie neopitagorejskie, przekonanie, że porządek muzyczny jest dźwiękową realizacją pozaczasowego, bo należącego do bytu, a nie stawania się, numerycznego porządku wszechświata, w którym brzmiące dźwięki to w swojej istocie brzmiące liczby - numeri sonantes ${ }^{2}$. Rozważania Augustyna z De musica pośredniczą między pitagorejsko-platońskim nurtem greckiej filozofii muzyki (bo istniały też nurty zdecydowanie antypitagorejskie, jak epikureizm Filodemosa ${ }^{3}$ ) a teologią muzyki, która weźmie sobie za patrona, w charakterystyczny zresztą sposób, właśnie De musica, pismo powiązane z poglądami Augustyna sprzed jego chrześcijańskiej konwersji, oraz niechrześcijańskie Institutiones Boecjusza, co prawda w schrystianizowanej interpretacji gockiego uczonego Kasjodora. W tradycji greckiego Kościoła ortodoksyjnego, nurcie zainspirowanym pismami Pseudo-Dionizego Areopagity, rozwijanym przez Maksyma Wyznawcę i dogłębnie analizowanym przez Egona Wellesza4, wizja "wiecznych korzeni" muzyki znalazła wyraz w pełni już zgodny z neoplatońską interpretacją chrześcijaństwa. Brzmiące hymny, należące do hematon - świata zindywidualizowanych rzeczy i postrzegania zmysłowego, zostały uznane za byty emanacyjnie powiązane z ich noetycznymi pierwowzorami zawartymi w umyśle Bożym. Hymnom przynależy więc preegzystencja, a zadaniem śpiewaka, tak jak zadaniem piszącego ikonę, jest nie tyle tworzenie, co usuwanie zmysłowych przeszkód dla reprezentacji tego, co wieczne - odsłanianie w naoczności jej wiecznego pierwowzoru.

Z powodzeniem można by wskazywać analogiczne przykłady pochodzące z myśli nowożytnej, a nie tylko średniowiecznej. Bohdan Pociej ${ }^{5}$ chociażby, starając się objaśnić powiązanie muzyki i wieczności na nieprzypadkowym przykładzie twórczości Johanna Sebastiana Bacha, sięgał do filozofii muzyki Leibniza i sławnej idei „nieświadomego przeliczania duszy przez siebie samą". Dziewiętnasty wiek przyniósł, oprócz wizji romantycznych, także interpretacje $\mathrm{w}$ pełni zsekularyzowane, przeważnie zakorzenione w różnych postaciach filozofii transcendentalnej, a w wieku dwudziestym najczęściej formułowane $\mathrm{w}$ kategoriach fenomenologicznych. W taki czy inny sposób koncepcje te wiązały realne struktury dźwiękowe, oderwane od ich społeczno-kulturowych kontekstów, z jakąś postacią zawartości idealnej, a więc przywracały przekonanie o noetycznym w zasadzie charakterze mu-

\footnotetext{
2 Św. Augustyn, O muzyce, tłum. L. Witkowski, red. R. Popowski, Lublin 1999

${ }^{3}$ Filodemos, O muzyce. O utworach poetyckich. Epigramy, tłum. K. Bartol, Warszawa 2002

${ }^{4}$ E. Wellesz, Historia muzyki i hymnografii bizantyjskiej, tłum. M. Kaziński, Kraków 2006

${ }^{5}$ B. Pociej, Bach. Muzyka i wielkość, Kraków 1972
} 
zyki. Pomijam te sposoby myślenia, które chciałyby usunąć muzykę z pola tego, co czasowe i historyczne, poprzez jej powiązanie $z$ niezmiennymi jakoby, neurofizjologicznymi fundamentami wszelkiego tworzenia i doświadczania muzyki. Opcja ta nie należy do naszych rozważań, gdyż każdy, kto wyjaśnia muzykę $\mathrm{w}$ kategoriach biologicznych, pozostaje wewnątrz historii, nawet jeśli w wymiarze - rzekłby Fernand Braudel - najdłuższego trwania. Ludzki mózg jest bowiem wytworem ewolucji i ewolucji podlega, nie ma więc pozahistorycznych struktur mózgu. Trzeba by jakiejś absurdalnej neurofizjologii antyewolucjonistycznej, by usunąć się poza historię i czas.

Przekonanie o specjalnym powiązaniu muzyki i wieczności nie może być nawet traktowane jako element kulturowej differentia specifica europejskiej tradycji muzycznej. Oczywiście, przekonanie to nie posiada statusu takiego, jak na przykład posługiwanie się językiem czy zakaz kazirodztwa, a więc nie może pretendować do funkcji kulturowego uniwersalium. Nie tylko istnieją kultury, w których powiązanie takie się nie pojawia, ale też kultury, które nie zawierają nic odpowiadającego czy to chrześcijańskiej, czy filozoficznej idei wieczności i którym tego rodzaju przekonania można przypisać jedynie zajmując naiwną wersję postawy etnocentrycznej (etnocentryzmem nienaiwnym nazwałbym postawę taką, kiedy ktoś świadom historycznego i względnego charakteru własnej kultury, uznaje tę kulturę za obowiązującą nie na mocy pomyłki poznawczej, lecz na mocy decyzji aksjologicznej przykładem postawa Ernsta Gellnera); aby przypisać tego rodzaju przekonanie na przykład północnoamerykańskim Arapajo, którzy twierdzą, że pieśni osobiste objawiane są człowiekowi przez jego ducha opiekuńczego, trzeba by zignorować fakt, że dla Arapajo ludzie i „duchy” należą do jednego planu egzystencji i nie występuje u nich żadna różnica między tym, co czasowe, i tym, co wieczne, między idealnym i realnym, a nawet nadprzyrodzonym i przyrodzonym. Nawet w tych kulturach, gdzie - jak w Europie czy w Hindustanie - powiązanie takie jest niezwykle ważne, bywa ono kontestowane i kwestionowane, czasem z wielką mocą. Epikureizm Filodemosa jest dobrym przykładem kontestacji pitagorejsko-platońskiej filozofii muzyki na gruncie antycznym, tak jak muzyce „wiecznej tęsknoty” poetów Sturm Und Drang, ale i Gustava Mahlera, przeciwstawia się pogardliwe nazwanie przez Jana Jakuba Rousseau wszelkich les concertes et les sonates - „przyjemnym szmerem". Niemniej jednak, powiązanie muzyki i wieczności wcale nie jest rzadkie i wcale nie jest specyficznie europejskie.

Dobrym przykładem spoza Europy jest hinduistyczna koncepcja ragi. Raga lub ragini - ragi posiadają bowiem płeć - to określony, boski byt osobowy. Ragi należą do orszaku tancerza Śiwy, który jest ich opiekunem, 
a więc także strażnikiem czysto techniczno-muzycznych reguł ragi. Wykonanie ragi jest zatem reprezentacją tego, co boskie, w iluzorycznym świecie indywiduacji i zmysłów i wcale musi być dźwiękowe - ragę można też namalować lub opowiedzieć. Realizacja muzyczna ragi ma jednak szczególny charakter, bowiem brzmiące dźwięki stają się żywym ciałem boga. Stąd też wyjątkowe znaczenie zachowania właściwych reguł ragi. Był kiedyś - mówi hindustańska opowieść - wielki muzyk, który wykonywał ragi na swój sposób, nie podążając za ich właściwymi regułami. Pewnej nocy objawił mu się Śiwa i zabrał do komnaty pełnej jęczących i okaleczonych mężczyzn i kobiet. Przerażony muzyk, nie mogąc znieść widoku takiego kalectwa, zapytał, kim są ci ludzie i dlaczego tak cierpią. „To ragi, które grasz” - odpowiedział Śiwa. Piękno ragi, jako brzmiącego tworu dźwiękowego, nie może być zatem w żaden sposób skażone chęcią autoekspresji czy osobowością muzyka. Improwizowany charakter ragi może zwieść Europejczyka i sugerować podobieństwo z jazzem. Trudno w rzeczywistości o opozycję silniejszą niż ta, która dzieli światy ragi i muzyki afroamerykańskiej. Piękno ragi ma być absolutne, a muzyk jest wyłącznie neutralnym naczyniem. Hindusi określają ten efekt terminem $\mathrm{ras}^{6}$. Zaznaczmy tylko na marginesie pewne uderzające podobieństwo, mimo wszelkich różnic, między koncepcją ragi a neoplatońską koncepcją preegzystującego hymnu. Jeden więcej przyczynek do aktualnej dyskusji o znaczeniu Indii dla greckiej filozofii.

Inne przykłady relacji muzyka - wieczność można odnaleźć chociażby w klasycznej tradycji chińskiej czy kulturach muzycznych Indonezji. Nie chodzi tu jednak o swoisty historyczny katalog takich powiązań - choć stworzenie takowego nie byłoby przedsięwzięciem błahym - chodzi raczej o unaocznienie wagi zagadnienia, które w rozważaniach kulturoznawczych prowadzi do niezwykle interesującego pytania o to, czy istnieje jakiś specyficzny dla gatunku homo sapiens tryb percepcji, który owocuje takim doświadczeniem zmysłowym, jakie $\mathrm{w}$ sprzyjających okolicznościach historycznych znajduje wyraz $\mathrm{w}$ powracającym odniesieniu tego, co zmysłowe, do tego, co wieczne. Można by wybrać drogę czystej analizy emicznej, która zapewne doprowadziłaby do anulowania rozważanej kwestii, gdyż szczegółowy rozbiór poszczególnych koncepcji pokazałby nieuchronnie, że ich podobieństwo jest efektem imputacji kulturowej. Jednak ograniczenia takiego podejścia są aż nazbyt dobrze znane, a swoistego podsumowania jego krytyki dokonali między innymi Marvin Harris - dla ogólnej teorii kultury i Jean-Jacques Nattiez - dla rozważań nad muzyką. Tutaj dodajmy jeszcze jedno zastrzeżenie. Oczywiście, istnieją fundamentalne różnice między - by

${ }^{6}$ Por. J. Bor, The Raga Guide, Charlottesville 1999 
trzymać się tylko Europy - wyobrażeniami wieczności jako nie-czasu, jako czasu nieskończonego i jako „wiecznego teraz” („okamgnienia”, jak pisał Nietzsche). Szczegółowa analiza pokazałaby więc zapewne, i na wyłącznie europejskim gruncie, iluzoryczny charakter jedności tego rodzaju doświadczenia. Problem polega jednak na tym, że muzycy, ich słuchacze, krytycy, a nawet zajmujący się muzyką uczeni, z rzadka jedynie bywają filozofami, a jeszcze rzadziej teologami. Chociaż powiązanie muzyki i wieczności bywało artykułowane filozoficznie i teologicznie, to jednak jego najważniejsze wyrazy mają charakter poetycki, nieformalny lub potoczny, a w dyskursie poetyckim i użyciu potocznym pojęcie wieczności jest niezwykle rozmyte, określa coś nieuchwytnego, coś spoza normalnego porządku rzeczy, coś, co łatwiej daje się określić jako przedmiot uczucia, ku któremu kieruje się „nieskończona tęsknota”, niż jako pojęcie (chociaż charakteru pojęcia nie traci). Powtarzane jak zaklęcie słowo ewig, ewig w Pieśni o ziemi Gustava Mahlera ewokuje tę tęsknotę, a nie pojęcia filozofów i teologów. Pytanie pozostaje więc w mocy: czy istnieje taki tryb postrzegania, który niejako domaga się interpretacji w kategorii wieczności?

Najbardziej pobieżna obserwacja wskazuje, że pojęcie to regularnie wiązane jest $\mathrm{z}$ dwoma biegunami muzycznego doświadczenia, a $\mathrm{z}$ jego centrum - niezwykle rzadko. Mamy więc cały system świadomego ewokowania tego doświadczenia poprzez skrajne uproszczenie języka dźwiękowego, czasem połączone, jak w muzyce Arvo Pärta, z przywoływaniem elementów pamięci kulturowej poprzez odwoływanie się do łatwo rozpoznawalnej aury dawnej muzyki sakralnej, czasem wywodzące się, jak w przypadku Mortona Feldmana, z poetyk awangardowych i postawangardowych. Niektórzy krytycy posługują się nawet, $\mathrm{w}$ odniesieniu do kompozytorów z krajów poradzieckich, sarkastycznym określeniem holy minimalizm, żeby odróżnić go od zdecydowanie świeckiego minimalizmu twórców takich jak Philip Glass (czy jednak minimalizm Glassa był taki znowu świecki we wspólnym projekcie z Robertem Willsonem poświęconym mędrcom sofizmu?). Na drugim biegunie mamy powiązanie wyobrażenia wieczności - jeśli wieczność może być wyobrażona - z muzyką o najwyższym stopniu złożoności: $\mathrm{z}$ takimi dziełami Bacha, bez względu na ich genezę, jak Kunst der Fuge lub Das musikalisches Opfer, z ostatnimi kwartetami smyczkowymi i sonatami fortepianowymi Beethovena, z kontrapunktyczną zawiłością muzyki Jeana Ockeghema, z muzyką Oliviera Messiaena. Powiązanie wieczność - złożoność jest szczególnie frapujące, bo zdaje się zamierać po przekroczeniu pewnego progu złożoności - powszechnie wiąże się je z powyższymi przykładami, ale nie z dziełami jeszcze bardziej złożonymi, jak Młot bez mistrza Pierre'a 
Bouleza czy kompozycje Miltona Babbitta. Najrzadziej chyba jednak wieczność pojawia się jako kategoria interpretacyjna w muzyce utrzymującej swoistą równowagę prostoty i złożoności - nie znam żadnego przykładu interpretowania w ten sposób twórczości Haydna czy Mendelssohna, a jeśli już, to niezbędna okazuje się najczęściej droga pośrednia: albo wiodąca poprzez powiązanie owej równowagi z kategorią piękna, a dopiero piękna z wiecznością (powstaje jednak $\mathrm{w}$ ten sposób wytrych interpretacyjny, który da się powiązać z każdym doświadczeniem piękna), albo też na drodze złożonej spekulacji, jak dosłuchiwanie się przez Hermana Hessego „wiecznego śmiechu” w muzyce Mozarta. Biegun złożoności wydaje się szczególnie frapujący i jego też wybieram do dalszej analizy.

Skoro podejrzewa się, że za poszczególnymi artykulacjami relacji muzyka - wieczność stoi bardziej ogólny typ doświadczenia, to rozważania wypada zacząć nie na poziomie kulturoznawczym, lecz estetycznym. W grę wchodzi bowiem bez wątpienia jakieś szczególne doświadczenie z zakresu aisthesis oraz jego rozmaite upostaciowania.

W Krytyce wtadzy sądzenia Kant wzmiankuje o odniesieniu sztuki do nieskończoności, nie odnosząc go do zagadnienia złożoności percepcyjnej. Czyni to przy okazji rozważań nad wzniosłością matematyczną i jego uwaga tworzy, mimo iż sformułowana w odmiennym kontekście, najlepszy punkt wyjścia dla dalszych analiz ${ }^{7}$.

Przejmując od szkockich empiryków samo pojęcie wzniosłości jako nazwę dla takiego doświadczenia estetycznego, które nie podpada pod doświadczenie piękna $\mathrm{w}$ żadnej jego postaci, nie wiąże się więc $\mathrm{z}$ wydaniem ani czystego, ani stosowanego sądu smaku, Kant odrzuca zarazem fizjologiczne wyjaśnienie tego doświadczenia, jakie zaproponował Edmund Burke. Kanta interesuje oczywiście gra władz poznawczych $w$ tego rodzaju doświadczeniu, zwłaszcza stosunek między intelektem i rozumem, a więc między naocznością a pojęciem, czyli opis i wyjaśnienie o charakterze transcendentalnym. Jak wiadomo, Kant rozpatruje dwie odrębne grupy doświadczeń wzniosłości, za którymi jednak kryje się ta sama dynamika naoczności i pojęcia. Są to: wzniosłość matematyczna i dynamiczna wzniosłość przyrody.

Dynamiczna wzniosłość przyrody to doświadczenie dwuetapowe, które wiąże się z manifestacją niszczycielskiej mocy przyrody, taką jak klęski żywiołowe, atak drapieżnika itp. Oczywiście, warunkiem estetycznego odbioru tego rodzaju zjawisk jest własne bezpieczeństwo obserwatora; by tak to wyrazić: atakujący lew nie jest wzniosły dla celu ataku. Jako doświadczenie naoczne jest to doświadczenie przykre, albo i wręcz druzgocące. Zostaje

${ }^{7}$ Zob. I. Kant, Krytyka władzy sądzenia, tłum. A. Landman, Warszawa 2004. 
bowiem w nim zakwestionowany sam byt człowieka jako istoty zmysłowej. Niszczycielska moc natury ujawnia całą przypadkowość i nieistotność naszego fizycznego bytu. Klęska żywiołowa niszczy w sposób, dla którego nie istnieje żadne racjonalne kryterium. Wszelkie poczucie sensowności istnienia zostaje zakwestionowane, a waga wszelkiego ludzkiego wysiłku - zniesiona. Cokolwiek zrobimy, kimkolwiek jesteśmy, wobec mocy przyrody jesteśmy niczym. Jednak owo całościowe zakwestionowanie wszelkich pretensji, jakie może posiadać człowiek - zarówno wszelkiej szczególności osobistej, jak i domniemanej wyjątkowości gatunkowej - utrzymuje się w mocy jedynie w wymiarze naoczności. Drugą częścią bowiem doświadczenia dynamicznej wzniosłości przyrody, częścią niejako pozytywną, jest ukonstytuowanie tej strony bycia człowiekiem, która nie podlega władzy przyrody i której żadna naturalna destrukcja nie jest w stanie unicestwić. Aby to dobrze zrozumieć, posłużmy się dość niekantowskim przykładem. Wyobraźmy sobie człowieka, który ginie, próbując ratować kogoś z ognia. Większość $\mathrm{z}$ nas bez dłuższego wahania określiłaby jego śmierć jako wzniosłą. Z perspektywy Kantowskiej chodzi tu o to, że fizyczne zniszczenie owego człowieka, a więc - w kategoriach naoczności - przypadkowość i nieistotność jego wysiłku, w niczym nie zmienia moralnej wartości czynu. Zdolność przyjęcia groźby albo gotowość na unicestwienie jest tutaj z nawiązką równoważona przez moc normy moralnej - a więc pojęcia rozumu - której nie mogą znieść przypadkowe okoliczności przyrody. W takim więc razie określanie tego czynu mianem wzniosłego wiąże się z dostrzeżeniem rozumowego jądra, które znajduje się poza władaniem przyrody. Tym więc pozytywnym doświadczeniem $\mathrm{w}$ ramach dynamicznej wzniosłości przyrody jest doświadczenie siebie jako rozumu, w przeciwieństwie do siebie jako naoczności, a zarazem utrwalenie autonomii tego, co rozumne. Doświadczenie to, jako formę gry między władzami poznawczymi człowieka, można najkrócej opisać wedle własnego określenia Kanta - jako doświadczenie nieskończonej przewagi rozumu nad naocznością; dodajmy jednak, że nie chodzi o doświadczenie spekulatywne, lecz estetyczne. Kant, jak samo określenie „dynamiczna wzniosłość przyrody" wskazuje, nie rozważa innych źródeł takiego doświadczenia niż manifestacja sił przyrody. Odniesienie tego do sztuki, a zwłaszcza muzyki - tego ostatniego na pewno nie dokonałby Kant - jest rzeczywiście niezwykle trudne, choć nic go z góry nie wyklucza.

Jest jeszcze jednak druga forma doświadczenia wzniosłości - wzniosłość matematyczna. W tym przypadku punktem wyjścia jest doświadczenie ogromu. Ogrom to taki rząd wielkości, który wyklucza możliwość całościowego ujęcia przez spostrzeżenie zmysłowe. Olbrzymia góra oglądana jest 
fragment po fragmencie i nigdy nie ujawnia się postrzeganiu jako jednorazowo dany obiekt. Nawet jeżeli reprezentuje taki typ organizacji formalnej, który podpadałby pod kategorię piękna, a więc - w kryteriach Kantowskich - pustą formę celowości, to w tym wypadku doświadczenie piękna nie może się ukonstytuować jako doświadczenie estetyczne, gdyż zmysłowe ujęcie ogromu, a więc także wszelkiej ewentualnej formy tego ogromu, przekracza możliwości jakiejkolwiek aisthesis. Ogrom jest zatem czymś, co osiąga i przekracza kres naszych możliwości percepcyjnych, unieważniając pretensje do skuteczności naocznego poznania. Jest to więc raz jeszcze, choć w zupełnie inny sposób, doświadczenie bankructwa naoczności. Co jednak nie może być zsyntetyzowane $\mathrm{w}$ akcie postrzegania zmysłowego, może $\mathrm{zy}$ skać całościowy wymiar poprzez syntetyzujące pojęcie rozumu. Takim pojęciem jest na przykład nieskończoność - Kantowski przykład pojęcia służącego do syntetyzowania tego rodzaju doświadczeń, których nie daje się ująć naocznie. Ogrom ewokuje więc pojęcie nieskończoności.

Dynamika wzniosłości matematycznej jest zasadniczo taka sama jak dynamicznej wzniosłości przyrody - także i w tym przypadku bankructwu naoczności towarzyszy triumf rozumu; a zatem określenie „doświadczenie nieskończonej przewagi rozumu nad naocznością" może służyć za najbardziej ogólny opis transcendentalnej struktury wzniosłości.

Wzniosłość matematyczna jest jednak stowarzyszona także z innego rodzaju doświadczeniem, czyli z monstrualnością. To, co monstrualne, nie może być zsyntetyzowane ani przez naoczność, ani przez pojęcie rozumu. Monstrualność stanowi więc jednoznacznie negatywne doświadczenie estetyczne. Ze względu za zaangażowanie nie tylko intelektu, ale też rozumu, w przypadku wzniosłości i monstrualności poprawniej byłoby zresztą może mówić nie tyle o doświadczeniu estetycznym, co raczej o doświadczeniu o estetycznym punkcie wyjścia. Warto przy tym zwrócić uwagę na fakt, że stosunek między naocznością a pojęciem jest tutaj zupełnie inny niż w przypadku pulchritudo adherens, gdzie między zmysłową formą piękna a pojęciem zachodzi relacja instrumentalnego podporządkowania.

Nawet pierwsza intuicja wskazuje, że rozważania Kanta stanowią właściwie obowiązkowy punkt wyjścia dla pytania o relację jakiegokolwiek postrzegania zmysłowego, w tym oczywiście percepcji muzycznej, do pojęć rozumu, takich jak na przykład wieczność. Nie da się jednak do muzyki odnieść tak po prostu żadnego z dwóch doświadczeń wzniosłości, które opisał Kant. Dynamiczna wzniosłość przyrody wydaje się odpadać całkowicie, natomiast zasada wzniosłości matematycznej kazałaby wiązać tego rodzaju doświadczenia wyłącznie z jakąś postacią muzycznego ogromu, choć- 
by z tetralogią Richarda Wagnera albo Symfonia Tysiaca Gustava Mahlera (nie bez powodu Mahler mówił o niej pieszczotliwie "meine Ungeheuer"). Można by podjąć taką arbitralną decyzję, ale usunęlibyśmy z pola rozważań przykłady najbardziej oczywiste - fugi z Die Kuns der Fuge, które angażują minimalny aparat wykonawczy i trwają po kilka minut, całkowicie mieszcząc się w możliwościach syntezowania ludzkiej pamięci. Lepiej więc wyjść od ogólnej zasady dwuetapowości doświadczenia i specyficznej relacji między naocznością a pojęciem, oraz zapytać o to, czy istnieją inne niż opisane przez Kanta możliwości realizacji doświadczenia o takiej samej strukturze. Doświadczenie złożoności wydaje się spełniać wymagania takich rozważań.

Chodzi tutaj o złożoność estetyczną, czyli o taki rodzaj zorganizowania naoczności, który przez bogactwo i komplikację strukturalną uniemożliwia całościowe ujęcie zmysłowe. Tego rodzaju złożoność estetyczna miałaby w sąsiedztwie dwa odmienne doświadczenia: piękna formalnego i monstrualności. Piękno formalne, pusta forma celowości, jest cechą naoczności tak zorganizowanej, że wzajemne relacje w jej wnętrzu jawią się percepcji zmysłowej - niekoniecznie przy pierwszym oglądzie - jako w pełni uchwytne i w sposób doskonały zorganizowane. To, co monstrualne, posiadałoby z kolei konstrukcję o złożoności niemożliwej do rozwikłania dla postrzegania zmysłowego, a przez to niepodlegającej naocznościowej syntezie. Monstrualność musiałaby jednak także spełniać drugi warunek, wynikający ze sposobu, w jaki kategorię tę usytuował Kant względem wzniosłości matematycznej - nie może dla niej istnieć syntetyzujące pojęcie rozumu, to znaczy: myślenie pojęciowe nie potrafi dokonać syntezy naocznej struktury i ponosi tę samą, co i postrzeganie zmysłowe, porażkę. To, co monstrualne, jawi się zatem zarazem jako absurdalne i pozbawione sensu (może jednak istnieć $\mathrm{i}$, jak wiadomo, historycznie istniała tego rodzaju poetyka, która właśnie absurdalność waloryzuje pozytywnie, bowiem, wbrew późnemu, osiemnastowiecznemu przekonaniu, sztuka wcale nie musi być ze swej istoty estetyczna). Między pięknem formalnym a monstrualnością należałoby umieścić „wzniosłą złożoność”.

Określiłbym $\mathrm{w}$ ten sposób takie dwuetapowe doświadczenie, w którym poziom złożoności artystycznego ukształtowania tworu zmysłowego jest tak szczęśliwie dobrany, że postrzeganie zmysłowe nie potrafi odnaleźć zasady porządku i dokonać właściwej syntezy doświadczenia, ale zarazem odnajduje o gólne wrażenie ładu, które usprawiedliwia przejście od zmysłowego do rozumowego poszukiwania tegoż ładu zasad. Ta ostatnia uwaga stawia zresztą $\mathrm{w}$ nieco innym świetle zagadnienie złożoności monstrualnej. Być może należałoby nim objąć nie tylko doświadczenie podwój- 
nego bankructwa zarówno naoczności, jak i rozumu w starciu z czymś niezwykle złożonym, ale też takie zmysłowe doświadczenie czegoś złożonego, które - choć owo coś posiada racjonalną regułę porządku - nie zawiera w sobie zmysłowego przeczucia ukrytego ładu i nie prowokuje nawet próby przejścia do szukania jego rozumowej zasady. Tłumaczyłoby to na przykład negatywne reakcje estetyczne na muzykę serialistyczną. Owo doświadczenie przeczucia ukrytego ładu, którego nie ogarniają z m y sły , wydaje się sednem „wzniosłej złożoności”. Wydaje się, że takie przeczucie może uruchomić dwie różne kontynuacje. Pierwszą jest rzeczywiste poszukiwanie racjonalnych zasad tego ładu. Jest to jednak doświadczenie dostępne, zwłaszcza w odniesieniu do muzyki, dopiero od pewnego poziomu wiedzy profesjonalnej i - pomijając krąg najbardziej wyrafinowanych odbiorców - bez wątpienia rzadkie. Drugą możliwością kontynuacji przeczucia ładu, której nie można uznać za niewłaściwą czy zastępczą, jest z kolei ciąg substytucji pojęciowych, który przewidział już Kant, pisząc o ogromie. Reguła ładu jawi się zatem jako - w sensie całkowicie dosłownym - nieogarniona lub niepojmowalna, choć odczuwalnie obecna. Uruchamia to ciąg pojęć, który zarówno myślenie poetyckie, jak i potoczne - bez względu na obiekcje filozofów lub teologów - uważa za pokrewne lub nawet synonimiczne: niepojmowalne = boskie = wieczne. Wydaje się zatem, że wiązanie kategorii wieczności ze złożoną muzyką jest pewną specjalną wersją wzniosłości w rozumieniu Kanta i opiera się właśnie na owej substytucji pojęciowej. Dokładniej rzecz ujmując, chodzi o jeden tylko z możliwych typów powiązania muzyka - wieczność, istnieją bowiem bez wątpienia inne jego wersje.

Zanim przejdziemy do przykładów muzycznych, potrzebnych jest kilka jeszcze uwag już o kulturoznawczym, a nie estetycznym charakterze. Otóż próg złożoności, który zdaje się uruchamiać sugerowany powyżej typ doświadczenia, zależy nie tylko od ogólnoludzkich właściwości naszego aparatu zmysłowego (chociaż i w jego czułości występują różnice osobnicze), ale przede wszystkim od muzycznej enkulturacji. Mam tu na myśli nie tylko nabywaną $\mathrm{w}$ toku edukacji muzycznej profesjonalną wiedzę, choć jej znaczenia nie da się oczywiście zbagatelizować, gdyż orientacja w strukturze muzycznej jest w najwyższym stopniu zależna od zdolności do jej pojęciowego opisu i systemu oczekiwań towarzyszącego samemu aktowi słuchania. Wiedza o możliwych typach kształtowania muzycznego pozwala na wstępne rozpoznanie struktury. Mówiąc najprościej, inaczej w złożoności fugi orientuje się ktoś, kto z góry wie, jakie są tejże fugi ogólne zasady, typy, i zna odpowiednią ilość praktycznych jej realizacji. Nie znaczy to jednak, że 
słuchacz „nieprofesjonalny” znajduje się na jakiejś z góry przegranej pozycji. Enkulturacja muzyczna bowiem to $\mathrm{w}$ pierwszym rzędzie nie nabywanie wiedzy pojęciowej, ale kształtowanie nawyków percepcyjnych, sposobów słyszenia; by tak rzec: strukturowanie zdolności do aisthesis. Jest to doświadczenie doskonale znane etnomuzykologom napotykającym $\mathrm{w}$ badaniu muzyki obcych kultur właśnie próg o charakterze percepcyjnym, a nie pojęciowym, wynikający z odmiennych enkulturacji. Mantle Hood analizował tego

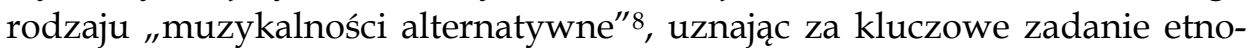
muzykologa wykształcanie w sobie innej niż europejska muzykalności, przy czym muzykalność oznacza tutaj zdolność do czysto zmysłowego ujmowania relacji między dźwiękami. Słuchaczom o odmiennej enkulturacji muzycznej inne rzeczy wydają się złożone, a odmienność ta może sięgać aż do słyszenia kulturowo obcej muzyki jako monstrualnego chaosu. Oczywiście, także wewnątrz względnie jednolitej wspólnoty muzycznej istnieją indywidualne różnice $\mathrm{w}$ tak pojmowanej muzykalności. To, co estetyczne, i to, co pojęciowe, nie jest tu zresztą łatwe do odróżnienia, gdyż choć enkulturacja muzyczna obejmuje $\mathrm{w}$ pierwszym rzędzie formowanie postrzegania zmysłowego, to czynnika pojęciowego nie jest, oczywiście, wyzbyta.

Uwzględnienie enkulturacji i różnorodności dystrybutywnie rozumianych kultur muzycznych rzuca światło na pewne ciekawe współczesne zjawisko z zakresu tak zwanej world music: otóż dla wielu europejskich słuchaczy, których rodzaj muzykalności nie pozwala na właściwe orientowanie się np. w muzyce rdzennych Amerykanów czy Tajów, każda muzyka nieeuropejska wydaje się sakralna czy rytualna. W szczególności ideologia New Age chętnie łączy mgliście rozumiane doświadczenie mistyczne z dowolną właściwie muzyką nieeuropejską. Zjawisko to przybiera zabawne czasem kształty. Moi studenci mówili o takich właśnie quasi-rytualnych doświadczeniach w kontekście tworów muzycznych, które w oryginalnym kontekście kulturowym posiadają diametralnie inny charakter (chodziło o pieśń zalotną Navajo oraz muzyczny agon Inuitów, tzw. katajjaq). Zdaje się, że właśnie ów brak orientacji, spowodowany odmienną enkulturacją muzyczną, w połączeniu z ogólnym odczuciem pewnego ładu w muzyce nieeuropejskiej, prowadzi niektórych słuchaczy ku doświadczeniu „wzniosłej złożoności" przy właściwie każdym kontakcie z muzyką kulturowo obcą. Doświadczenie to jest bez wątpienia kulturowo nieadekwatne, ale - jak widzimy - niebezpodstawne.

Należałoby zresztą mówić nie o jednym, lecz o kilku progach złożoności percepcyjnej. Pierwszy z nich określiłbym mianem progu uwagi. Osiąga go

${ }^{8}$ M. Hood, The Challenge of Bi-Musicality, „Ethnomusicology” 1960, vol. 4, no 2. 
muzyka wystarczająco złożona, aby pobudzić nasze procesy kognicji i wydobyć się $\mathrm{w}$ ten sposób $\mathrm{z}$ tła, stając się figurą percepcji. Chodzi więc o to samo zjawisko, które w zupełnie innych kategoriach Roman Ingarden opisywał jako „emocję wstępną", stanowiącą punkt wyjścia doświadczenia estetycznego. Można następnie mówić o progu trwałego zainteresowania. Próg ten osiąga muzyka o takim stopniu złożoności, który gwarantuje uruchomienie procesów kognicji za każdym razem (idealizując, bo możemy na przykład być zbyt zmęczeni), przy wielokrotnym kontakcie. Przekroczenie tego progu odpowiada za pewien specjalny typ doświadczenia muzycznego, przejawiający się w tym, że wielokrotny kontakt z wystarczająco złożoną muzyką nie tylko nie prowadzi do jakiejś formy „zblazowania”, lecz - paradoksalnie - wzmaga zainteresowanie, prowadząc do przekonania o niewyczerpywalności doświadczenia muzycznego. Jako trzeci należałoby podać próg wzniosłej złożoności, a więc próg, po przekroczeniu którego synteza doświadczenia zmysłowego może być dokonana dopiero po przejściu do syntezy pojęciowej, czy to $\mathrm{w}$ formie analityczno-strukturalnej, czy to przez substytucję pojęciową. Próg czwarty to oczywiście opisywany wcześniej próg monstrualności, poza którym synteza doświadczenia nie jest już możliwa. Nie trzeba chyba dodawać, że wszystkie te progi są wrażliwe na typ enkulturacji muzycznej i poziom indywidualnych kompetencji słuchacza. Osobiście znam wielu takich słuchaczy, dla których Carmina Burana Carla Orffa jest świetnym przykładem muzyki budzącej trwałe zainteresowanie, podczas gdy dla mnie osobiście utwór ten, skądinąd pamiątka po Jugendkultur w wersji SS, ledwie osiąga próg uwagi.

Drugi komentarz kulturoznawczy dotyczy owych substytucji pojęciowych i być może wyjaśnia, dlaczego w jednych kulturach odpowiednio złożona muzyka może być wiązana $\mathrm{z}$ pojęciami takimi jak wieczność, a w innych nie. Substytucje pojęciowe mają oczywiście charakter językowy. Po pierwsze więc, język danej wspólnoty musi zawierać odpowiednie narzędzia dla artykulacji tego rodzaju pojęć. Powiązanie pewnego doświadczenia muzycznego na przykład z ideą wiecznego Boga ze względów oczywistych nie może być dokonane przez słuchacza, którego język nie zawiera odpowiednich ku temu określeń. Nie chodzi przy tym, rzecz jasna, po prostu o słowa. Od czasów Herdera, a najpóźniej von Humboldta, wiadomo, że semantyczna i gramatyczna konstrukcja języków zawiera w sobie określoną wizję świata, rozstrzygnięcia o charakterze ontologicznym i kategorialnym. Być może granice języka nie są granicami doświadczania świata, ale z całą pewnością są granicami myślenia o świecie i mówienia o nim, granicami poznania pojęciowego. Jak ujął to Ludwig Wittgenstein: „o czym nie można 
mówić, o tym trzeba milczeć". Nie będzie więc ciągów substytucji pojęciowych prowadzących do takich pojęć, jak wieczność, wewnątrz takich obrazów świata, które nie zawierają kategorii tego, co wieczne. Dobrym przykładem są choćby języki algonkińskie lub języki grupy sju. Doświadczyli tego misjonarze próbujący wyłożyć ideę osobowego Boga chrześcijaństwa w tych właśnie językach. Aby dokonać przekładu, misjonarze ci musieli właściwie pracować nad przebudową całego obrazu świata. Jak wiadomo, ostatecznie nadali znaczenie Boga-osoby algonkińskiemu terminowi manitou i sjuańskiemu wakan (trudniej było z irokeskim orenda czy polinezyjskim mana). Są to te terminy, które Marcel Mauss uważał za nazwy bezosobowej mocy magicznej ${ }^{9}$, a które - jak to potem wykazał Claude Lévi-Strauss ${ }^{10}$ zdają się posiadać charakter "wolnego znaczącego": signifiant pozbawionego signifié, a przez to będącego do dyspozycji jako określenie dla wszystkiego, co nie mieści się $\mathrm{w}$ nazwanym porządku rzeczy. Takim wolnym znaczącym jest dla Dakotów wakan. Pies to w ich języku sunka, a więc nieznany im koń, przychodzący spoza porządku nazwy, został nazwany sunka wakan. Aby uczynić słowo wakan lub analogiczne algonkińskie manitou przekładem dla indoeuropejskiego „Bóg”, trzeba zmienić całą konstrukcję świata, jaka stoi za tymi językami. Można by mnożyć przykłady tego rodzaju: spróbujmy na przykład oddać w jakimkolwiek języku indoeuropejskim zakres znaczeniowy japońskiego kami... Nie chodzi jednak oczywiście o podawanie kolejnych przykładów, lecz o unaocznienie tego, że substytucje pojęciowe prowadzące od muzyki do wieczności wymagają pewnego specyficznego, jak nazywał to Lucien Febvre, outilage mental - „wyposażenia umysłowego". Jedne kultury wyposażenie takie oferują, inne nie. Nie należy tego zapewne rozumieć w jakimś ścisłym sensie determinującym, bowiem wszelkie normy kulturowe można też traktować narzędziowo. Należałoby zatem nie tylko pytać o to, jak pewne wyposażenie umysłowe determinuje obraz świata, ale też o to, co niezwykłego z jego pomocą da się zrobić. Ludzka pomysłowość $\mathrm{w}$ tym zakresie nie zna granic. W szczególności słuchacz musi być $\mathrm{w}$ stanie czy to na mocy już istniejących stowarzyszeń pojęciowych, czy to twórczego wykorzystania własnego wyposażenia umysłowego - połączyć niepojmowalność z wiecznością. Bezpośrednim bowiem doświadczeniem, a także nieuchronnym punktem wyjścia w kontakcie $\mathrm{z}$ wystarczająco złożoną muzyką, jest właśnie doświadczenie niepojmowalnego ładu.

\footnotetext{
${ }^{9}$ M. Mauss, Socjologia i antropologia, tłum. J. Szacki, Warszawa 2001.

10 Zob. C. Lévi-Strauss, Wprowadzenie do myśli Marcela Maussa, tłum. M. Król, K. Pomian, w: ibidem.
} 
Tradycja chrześcijańska wydaje się najbardziej przyjaznym gruntem dla dokonywania tego rodzaju substytucji. Sprzyja im utrwalona przez teologię apofatyczną, a pochodząca od św. Augustyna i Pseudo-Dionizego Areopagity, koncepcja niepojmowalności Boga. Będąc zawsze Innym względem każdego możliwego określenia, chrześcijański Bóg nie może być pojęty $\mathrm{w}$ żadnych ludzkich kategoriach. To, co niepojęte, na przykład pewien skomplikowany porządek muzyczny, staje się dzięki temu nie tylko zrozumiałym, ale wręcz uprzywilejowanym symbolem Boga. Charakter samego doświadczenia jest przy tym zależny od przyjmowanego statusu symbolu. Symbol może bowiem być pojmowany na sposób nowożytny, jako zjawisko semiotyczne, i stanowić rodzaj znaku. Można też jednak symbol pojmować ontologicznie, to znaczy nie jako oznaczanie, lecz uobecnianie tego, co symbolizowane. Jeśli więc trudna do pojęcia złożoność muzyczna staje się symbolem niepojmowalnego Boga, to mogą się za tym kryć dwa różne stany rzeczy: albo apofatyczne oznaczanie bóstwa, albo doświadczenie jego żywej obecności w symbolu. To, którego rodzaju doświadczenie zachodzi, jest w sposób oczywisty zależne od kulturowego statusu symbolu.

Uproszczona historia kultury kazałaby wiązać symbol rozumiany semiotycznie ze społeczeństwami nowożytnymi, a symbol rozumiany ontologicznie - $\mathrm{z}$ kulturami magicznymi; $\mathrm{w}$ kontekście europejskim natomiast $\mathrm{z}$ „mentalnością średniowieczną". Nazywam tę historię kultury uproszczoną, ponieważ z powodów, które domagają się osobnej analizy, traktuje ona przemiany świadomościowe, obejmujące za każdym razem węższą elitę, jako kulturowo miarodajne. Dzięki takiemu zawężeniu spojrzenia historia ta może nawet wierzyć w rozwojowy charakter struktur myślenia. Historycy kultury ludowej, od Michaiła Bachtina po włoską szkołę historii religii, w tym Carlo Ginsburga, dali nam aż nazbyt wiele mocnych powodów, by tej uproszczonej historii kultury zupełnie nie ufać. Bardziej przekonująca niż uproszczona wersja wizji kolejnych odczarowań świata jest heglistowska koncepcja nierównoczesności tego, co równoczesne. Oznacza ona, najprościej rzecz ujmując, że każdy stan historyczny ducha w ścisłym rozumieniu, a więc samointerpretującego się myślenia (lub życia - jak powiedzieliby zwolennicy Wilhelma Diltheya), zawiera współegzystujące rozmaite warstwy chronologiczne. Zatem świadomość nazywana archaiczną nie przynależy tak po prostu społeczeństwom dawnym, ale też działa aktywnie obok nas, jako pomijana milczeniem, bo niemieszcząca się $\mathrm{w}$ schemacie postępu, forma ludzkiego myślenia. Historia form świadomości czy też sposobów myślenia jest, jak każda inna historia, polichroniczna, to znaczy - zawiera procesy o rozmaitym tempie i różnych wymiarach trwania. Te różne wy- 
miary trwania wchodzą ze sobą $\mathrm{w}$ interakcje, nazwane przez Fernanda Braudela "dialektyką historii". Oznacza to, że ontologiczne rozumienie symbolu, chociaż w żadnym razie nie wygasło, musi się dzisiaj sytuować wobec sposobów myślenia innych niż wtedy, gdy artykułowali je na przykład paryscy wiktorianie. Nie jest ono zatem prostą kontynuacją przeszłości. Niemniej nie można w imieniu sposobów myślenia niezwykle wąskiej elity, traktującej czasami systemy semiotyczne jako autoreferencyjne (czasami, bo nawet Derrida, gdy kupował bułki, musiał się posługiwać językiem „naiwnie"), bagatelizować współczesnej roli symbolu jako uobecnienia.

Warto jeszcze zapytać o to, dlaczego tak łatwo dokonuje się w kręgu europejskim, ale też $\mathrm{w}$ północnych Indiach, przejścia od muzycznego doświadczenia niepojmowalnego ładu właśnie do pojęcia wieczności, a nie któregoś innego z pojęć z nim stowarzyszonych. Otóż w chrześcijaństwie istnieje zakorzenione wyobrażenie wieczności jako nie-czasu, czyli rzeczywistości, która wymiaru czasu nie posiada, w przeciwieństwie do wizji wieczności jako czasu nieskończonego lub „odwiecznego”. Podobnie w hinduizmie, zwłaszcza w hinduizmie Upaniszad, czas jest nieodłącznym atrybutem empirycznego świata indywiduacji, świata zasłony Mai, w przeciwieństwie do pozbawionego wymiaru czasu - wiecznego Brahmana. W obu więc przypadkach czas jest Innym wieczności i pozostaje z nią - poprzez negację - koniecznie związanym. Ten właśnie związek wydaje się nadawać organizacji czasu uprzywilejowaną pozycję jako symbolowi wieczności. Dla uczestnika kultury chrześcijańskiej czy hinduistycznej czas, który traci rozpoznawalność wskutek złożoności własnego przebiegu, a więc skrywa pewną tajemnicę, zdaje się wskazywać nieuchronnie na swoje Inne, czyli wieczność. Złożoność muzyczna jest właśnie taką skomplikowaną strukturą czasu, a samą muzykę można by określić jako strukturowanie czasu za pomocą dźwięku. Temporalność muzyki nie jest niczym prostym, zwłaszcza w przypadku muzyki, jak europejska, pisanej, w której czasowe relacje między dźwiękami są wyobrażone i zapisane jako relacje przestrzenne (która więc dokonuje, wedle określenia Richarda Taruskina, spacjalizacji czasu muzycznego). Najważniejszym jednak jej aspektem wydaje się to, że kształtowanie muzyczne nie artykułuje czasu w kategoriach ilościowych, lecz artykułuje go jakościowo. Czas muzyczny może być gęsty lub rozrzedzony, przyspieszony lub zwolniony, prosty lub meandryczny, nawet piętrzyć się, jako złożona synchronia, lub zamierać. Słuchaniu muzyki przynależy to samo doświadczenie czasu, które starał się literacko uchwycić Bruno Schulz i które, zdaniem Paula Ricoeura, leży u podstaw wszelkiej narracyjności. Doświadczenia czasu i wieczności nie są zatem w muzyce sprzeczne, chodzi $\mathrm{w}$ nich bowiem o relację między doświadczaną strukturą czasu a symboli- 
zowanym Innym. Może więc to, że pewne kultury wyjątkowo intensywnie wiążą muzykę z doświadczeniem wieczności, nie jest żadnym przypadkiem, tak jak przypadkiem nie jest wydobywanie tego związku w sposobach myślenia szczególnie uczulonych na wizję świata jakościową, stojącą między innymi za niemiecką poezją romantyczną.

Odwołajmy się na koniec do muzycznego konkretu. Opierając się na analizach Dahlhausa i Frischa, Taruskin tak oto pisze o strukturze kwartetu smyczkowego c-moll op. 51 Johannesa Brahmsa:

Frazy i motywy są głównie identyfikowalne dzięki konturom - ich wznoszeniu się i opadaniu - oraz rytmowi. Jeśli chodzi o kontur, słabe części taktów drugiego, trzeciego i czwartego z podanego przykładu są wszystkie motywicznie równoważne, nawet jeśli interwały są różne: odpowiednio zmniejszona septyma, czysta kwinta i mała seksta. I tak oto, dzięki konturowi i umieszczeniu na końcu najdłuższego wznoszącego się ruchu, opadający półton w takcie siódmym może być także pojęty jako „motywiczny”, nawet jeśli wprowadza interwał jak dotąd właściwie nieużywany. Zbędnym jest dodawać, że raz oznaczony w ten sposób, jako tematycznie istotny, półton będzie teraz wykonywał wiele ważnych harmonicznych zadań o wzmożonym znaczeniu. A jednak, bez względu na to, jak ważna może być transformacja interwałów dla Brahmsowskiej "techniki rozwijającej się wariacji” (jak nazwał ją Arnold Schönberg, jej najbardziej fanatyczny naśladowca w przyszłym Wiedniu) interwałowa stałość gra rolę o równej, jeśli nie wyższej wadze. Ona także prowadzi do charakterystycznych rozwiązań. Na przykład partia drugich skrzypiec w taktach 1-3 jest całkowicie poświęcona wzmacnianiu $\mathrm{w}$ oktawie tercji C-Es $\mathrm{w}$ arpeggiach pierwszych skrzypiec i łączeniu jej z wypełnioną tercją w tym samym rejestrze, którą partia pierwszych skrzypiec się rozpoczyna. To także technika motywicznej ekstrakcji, potwierdzona przez rolę, jaką interwał tercji - zarówno jako skok, jak i jako „wypełniony" segment skali - będzie odgrywał w całości kwartetu. Oznaczmy pierwsze trzy nuty $\mathrm{w}$ partii pierwszych skrzypiec jako $a$, a dwie pierwsze nuty w partii drugich skrzypiec jako $a^{\prime}$ i będziemy przygotowani do prześledzenia oszałamiającej liczby powiązań, niektórych oczywistych, innych - tajemnych (ale gdzie przeprowadzić linię między jednymi i drugimi?, i kto powinien ją przeprowadzić?). Wstępna fraza drugich skrzypiec na początku drugiej części, by przytoczyć jeden przykład, jest w oczywisty sposób pewnym wariantem $a$, a główna melodia w pierwszych skrzypcach, już $w$ ten sposób prefigurowana, jest równie jasno zbudowana na inwersji $a$ poprzedzonej przez przedtakt i kontynuowanej za pomocą $a^{\prime}$. A jeśli pierwsze dwie części taktu melodii $\mathrm{w}$ drugim takcie drugiej części opisujemy jako inwersję $a$, to i dwie pierwsze części taktu trzeciego możemy opisać podobnie. A jeśli tak, to ostatnia część taktu trzeciego zawiera taką ekstensję inwersji $a$, aby objąć kwartę zamiast tercji. [...] Zauważywszy tyle, jesteśmy teraz przygotowani, aby odkryć że niemal każda nuta [...] jest wyprowadzana (lub wyprowadzana) z a lub $a^{\prime 11}$.

11 R. Taruskin, The Oxford History of Western Music, vol. 3, New York 2010, s. 735-736 (przekład własny). 
O tego rodzaju złożoność chodzi. Struktura kwartetu c-moll Brahmsa jest do rozwikłania dla analityka, chociaż - bądźmy szczerzy - zawsze pozostawia wątpliwości. W doświadczeniu słuchacza struktura ta jawi się jako ów „niepojęty porządek”. Niektóre spośród relacji strukturalnych są łatwe do słuchowego uchwycenia, inne - właściwie niemożliwe. Jeszcze inne sytuują się na granicy - słyszymy je lub nie w zależności od naszej koncentracji, albo też za jednym razem je słyszymy, a kiedy indziej nam umykają. Nigdy jednak nie ma wątpliwości, że za tym, co słyszymy, stoi absolutny porządek. Stąd się bierze niewyczerpywalność słuchania tej muzyki, gdyż pojedyncze wysłuchania kwartetu Brahmsa nie kumulują się w pełni aż do jakiegoś kompletnego poznania utworu. Zawsze coś umyka, zawsze trzeba coś poznać na nowo, nigdy też nie mamy pewności co do trafności odkrytych powiązań, przynajmniej tych "tajemnych". Z naszego punktu widzenia kwartet c-moll byłby znakomitym przykładem dzieła muzycznego, które powinno uruchamiać ciąg substytucji pojęciowych i procesów symbolizacji, o których pisałem wyżej. A jednak tak wyczulony na znaczenie słuchacz i tak wybitny muzykolog jak Richard Taruskin o takim wymiarze kwartetu Brahmsa nawet nie wspomina. Jego interpretacja ma charakter psychologiczny i społeczny:

\begin{abstract}
Aktywne zaangażowanie, zdolność odpowiadania na subtelne sygnały wymaga posiadania rzeczywistych umiejętności: rozróżniania słuchowego, słuchowej pamięci, umysłowej zręczności. Nagrody i satysfakcje są odpowiednie do trudności: euforia, która idzie za ćwiczeniem, gratyfikacja, która przychodzi ze zrozumieniem, poczucie partnerstwa zainspirowane odbiorem nagłego komunikatu. Ale jest także samozadowolenie oparte na przynależności do samozwańczej elity - emocja, która nagradza poprzez wykluczenie. I tu właśnie ezoteryczna, „trudna” sztuka nieuchronnie staje się kontrowersyjna w postarystokratycznej, „demokratycznej” epoce ${ }^{12}$.
\end{abstract}

Komentarz Taruskina nie jest bynajmniej bezpodstawny, ale zaskakujący w kontekście tez, które ośmieliłem się tutaj zaproponować. Tym większe więc zaskoczenie czeka czytelnika, który studiując dzieło Taruskina, dojdzie do jego komentarza na temat analogicznej złożoności muzyki Oliviera Messiaena. Kończąc rozważania nad symfonią Turangalîla i jej niezwykle złożoną strukturą, Taruskin pisze:

Jak wiele z tego miało być rzeczywiście „słyszane”? Jak wiele jest ledwie „notacją"? Figura bębna w przykładzie drugim jest oczywiście notacją, a nie dźwiękiem (dźwięk pojedynczego uderzenia w bęben trwający przez dwa takty nie może być nawet wyobrażony). Ale to nie było nic nowego. Podobnie przeładowane średniowieczne motety politekstualne sugerują odpowiedź na pytanie, od którego rozpoczął

12 Ibidem, s. 742. 
się ten akapit. Jak śpiewający orzeł powiedział do Dantego w jego Raju: „Jak są moje nuty dla was, którzy nie możecie za nimi podążać, taki jest Sąd Ostateczny dla was śmiertelnych". Gdzie ostateczna prawda ma być objawiona, zmysły muszą zostać przezwyciężone, umysł doprowadzony do wrzenia ${ }^{13}$.

Dlaczego więc doświadczenie wieczności jest uruchomione przez muzykę Messiaena, ale nie przez kwartet Brahmsa? Taruskin jest, by się tak wyrazić, za bardzo kulturoznawcą, by nie wiedzieć, że znaczenie dzieła sztuki jest wrażliwe na historię sposobów jego używania i rozumienia. Olivier Messiaen, jak Jan Sebastian Bach czy Jean Ockeghem, sam otoczył swoją twórczość dyskursem religijnym. Tymczasem historia recepcji twórczości Brahmsa - na szczęście lub nieszczęście powiązana z formalistyczną estetyką Eduarda Hanslicka - wyznacza tej muzyce inne miejsce i uruchamia inne domyślne sposoby interpretacji. Trzeba byłoby się zdobyć na wysiłek słuchania poza historią, aby usłyszeć w muzyce Brahmsa to, co w muzyce Messiaena wydaje się narzucać z mocą oczywistości. Dla tych z nas, którzy są po części chociaż historykami kultury muzycznej, takie usłyszenie muzyki może być nawet niewykonalne. Ktoś, kto usłyszałby wieczność w kwartetach Brahmsa, byłby - celowo przesadzam - w sytuacji bardzo podobnej do tego, kto słyszy ją w całej muzyce pozaeuropejskiej. Nie nazywam bynajmniej takiego słyszenia nieuprawnionym.

Związek zatem między doświadczeniem muzyki a wyobrażeniem wieczności, tak ważny dla niektórych sposobów myślenia o sztuce, nie wydaje się ani konieczny, ani arbitralny. Opiera się na grze poznania zmysłowego i zbiorowych wyobrażeń, w której odróżnianie czynników fizjologicznych, psychologicznych i społeczno-kulturowych pozostaje jedynie kwestią odmiennych języków analizy. Niewiele doświadczeń podważa ontologiczne rozumienie opozycji między tym, co naturalne, i tym, co kulturowe, tak gruntownie, jak doświadczenie muzyki.

\section{On Music Complexity and Some Specific Form of an Aesthetic Experience}

Summary

The main topic of the article is the explanation of repeatable interpretations of the experience of music in terms of the experience of eternity. The problem is approached by introducing Kant's concept of the mathematical/dynamic sublime and then by

${ }^{13}$ Idem, The Oxford History of Western Music, vol. 4, New York 2010, s. 242. Swoją drogą, ten właśnie komentarz Taruskina stał się inspiracją dla całych niniejszych rozważań. 
suggesting that the experience of the mathematical sublime can be also achived on a way which Kant did not analyze, i.e. thanks to the contact with aesthetical complexity. The conditions of such an experience are being researched. The second point of delibaration concerns the transition from experiencing the complex as sublime to interpreting it as symbol of the eternal. The examples used are coming mainly from the field of music, including J.S. Bach and O. Messiaen.

Słowa kluczowe: muzyka, kultura, wzniosłość, złożoność, estetyka, symbol

Keywords: music, culture, sublime, complexity, aesthetics, symbol

DOI: $10.14746 /$ cbes.2016.15.20 